\title{
Are Certain Dividend Increases Predictable? The Effect of Repeated Dividend Increases on Market Returns
}

\begin{abstract}
Positive abnormal returns around dividend increase announcements are well documented. The conventional explanation for these abnormal returns is that a dividend increase conveys favorable information about a firm's prospects causing the stock price to increase in response to the announcement. This study offers a new perspective by studying a special group of firms that consistently increase their dividends each year. Abnormal returns around each dividend increase announcement are investigated based on the number of consecutive annual increases. In light of survey results that indicate firms endeavor to maintain steady dividend payments, one hypothesis is that after a certain number of dividend increases, a firm may develop a reputation as a "dividend-increasing firm" and consequently the market will learn to anticipate future dividend increases. Consistent with this hypothesis, we find that abnormal returns are significantly positive for the first and second dividend increase. Returns are not significant for all other increases, with the exception of the ninth consecutive increase. Our results suggest that, by the third consecutive increase, the market has learned to expect further increases. Our findings are robust and provide further evidence that, consistent with other types of corporate announcements, the stock market reacts differently depending on the frequency of an action.
\end{abstract}




\section{Introduction}

There is a large body of evidence that shows that changes in corporate dividends are associated with abnormal stock returns and that the size of the dividend change is positively related to the size of the abnormal return. ${ }^{1}$ Moreover, survey evidence reveals that the most common objective of dividend policy decision-makers is to maintain constant or smoothly increasing dividend payments while avoiding dividend decreases. ${ }^{2}$ Consistent with these survey results, the empirical evidence in this study shows that, in practice, many firms' dividend policies are characterized by a pattern of steadily increasing dividends over time. Given that survey evidence reveals a clear desire to deliver steadily increasing dividends, and that dividend increases are associated with positive abnormal returns, a natural question arises: Do abnormal returns around dividend increase announcements differ depending on the firm's dividend history? This study seeks to answer this question by examining a large sample of repeated dividend increases. One hypothesis is that, if a firm has already increased its dividend several times, it may develop a reputation as a dividendincreasing firm. In this case, the market's anticipation of future dividend increases may result in lower observed abnormal returns when those dividend increases are announced since the expected increase will be impounded in the price prior to the announcement. If this hypothesis is true then one would expect that the number of prior increases might lead to more accurate predictions of future increases. For example, it is well-known that dividend initiations are associated with large positive abnormal returns. This finding is presumably due in large part to the unexpected nature of the change in the dividend from zero to a positive amount as well as due to the generally greater magnitude of the change in dividends at the initiation.

\footnotetext{
${ }^{1}$ Early work includes Pettit (1972) and Aharony and Swary (1980).

${ }^{2}$ See Lintner (1956) and Brav et al. (2005).
} 
Following similar reasoning, the first dividend increase after an initiation may be less expected than subsequent increases and consequently a larger positive announcementperiod abnormal return would be observed. However, it should also be true that the degree of surprise at the dividend increase announcement also depends on the length of time that has passed between one increase and the next.

To investigate our hypothesis, we identify the number of years of consecutive dividend increases for a sample of firms for dividend increases announced between 1999 and 2006. The abnormal returns are examined around the dividend increase announcement date after grouping each increase by its order of occurrence in the series of sequential increases. We find that the first and second increases exhibit significant positive abnormal returns, on average, while the abnormal returns surrounding the third and subsequent increases are not significant. This result remains after controlling for several firm characteristics and suggests that once a firm increases its dividend for two consecutive years, the market learns to anticipate future increases. While no analysis of the role of firm dividend histories and the effect on market returns currently exists, the market response to other repeated corporate events such as consecutive earnings increases have been examined. However, these studies do not examine abnormal stock returns around consecutive earnings increase announcements but instead investigate other aspects of the announcing firms' corporate performance.

The remainder of the paper is organized as follows: Section 2 provides the motivation for this study. Related research is discussed in Section 3. Section 4 explains the methods of data collection and sample construction, Section 5 presents the results and Section 6 contains our conclusions. 


\section{Motivation}

This study investigates series of consecutive annual dividend increases to determine if abnormal returns depend on the sequential placement of the dividend increase within the series. Past studies of the stock price behavior of dividend increasing firms document significant positive abnormal returns for a narrow two or three-day window around the time the dividend increase is announced. There is also a general consensus that the size of the return is related to the size of the dividend increase and to firm characteristics such as the market-to-book ratio and firm size. However, past studies have not recognized that the number of consecutive dividend increases may also be an important factor.

Surveys by Lintner (1956) and Brav et al. (2005) indicate that those persons responsible for setting dividends generally advocate a policy of steady dividend increases and avoidance of dividend decreases. Lintner develops a model that relates current dividends to past dividends and incorporates the target dividend payout ratio along with a speed-of-adjustment factor. Evidence in Fama and Babiak (1968) indicates that firms do indeed exhibit dividend policies consistent with Lintner's model.

If unexpected dividend increases are associated with increased value then when a dividend increase is announced by a firm without any previous dividend increases, the stock price should increase significantly due to the unexpected nature of the increase. However when a firm has a history of steadily increasing dividends over time, the market may come to expect further dividend increases by the firm, particularly if a clear pattern of increases has been established. Consequently, when future dividend increases are announced, the stock price may not increase significantly simply because the increase was fully or largely expected and therefore 
the information contained in the announcement has already been impounded in the stock price.

As a final point of motivation, Mergent and Standard \& Poor's have created a special category for firms that have a substantial history of consistent annual dividend increases. ${ }^{3}$ In addition, numerous mutual funds have been created that invest solely in firms that have consistently increased their dividends. The investor interest in these funds further motivates a study of this important subset of firms.

\section{Related Studies}

Numerous studies find that dividend increase announcements are, on average, associated with positive abnormal returns (e.g., Pettit (1972), Aharony and Swary (1980)). Many studies also find a significant relation between abnormal returns and various firm financial characteristics, such as dividend yield, firm size (Amihud nad Li (2006), the size of the dividend change (Yoon and Starks (1995)), market-to-book value (Lang and Litzenberger (1989)), investor's dividend preferences (Li and Lie (2006)), return on assets and systematic risk (Grullon et. al. (2002)), and the level of institutional ownership (Amihud and Li (2006)).

There have been only a few studies that investigate repeating corporate events. However, those studies generally find that the frequency of an event is important. For example, Barth, Elliott and Finn (1999) find that firms with at least five years of consecutive increases in annual earnings have higher price-earnings $(\mathrm{P} / \mathrm{E})$ multiples than other firms. Further, the P/E multiple increases for each additional year a firm extends the string of consecutive earnings increases. When the firms fail to increase earnings (by announcing instead a decrease in earnings), the string breaks and the

\footnotetext{
${ }^{3}$ Mergent designates any firm that has increased its dividend for at least ten or more consecutive years as a Dividend Achiever. A longer, twenty-five year history of consecutive annual dividend increases is required to be included in Standard and Poors' 'S\&P Dividend Growth U.S. Basket'.
} 
price-earnings ratio premium disappears. In contrast to Barth, et al. (1999) who use annual data, Myers, Myers and Skinner (2007) examine firms with at least five years of consecutive quarterly earnings increases. These firms earn positive abnormal returns for each year of the five year sequence of quarterly earnings increases. Further, abnormal returns for the quarterly-earnings-increase firms are larger than those of annual earnings increase firms. At the announcement of the first decrease in quarterly earnings, the sequence breaks and there is evidence of significantly negative abnormal returns. In addition, abnormal returns are more negative the longer the sequence of past increases in quarterly earnings.

Bartov, Givoly and Hayn (2002) find that firms with a record of announcing earnings that either equal or exceed analysts' forecasts in at least nine of the past twelve quarters display significantly higher abnormal returns around earnings announcements compared to firms without such a record. They argue that, while the market might discount these firms because such a record is suggestive of earnings management, their results instead suggest the market attaches a premium to these firms due to the expectation of improved future financial performance. In a similar study, Kasznik and McNichols (2002) analyze firms that announce one, two, or three consecutive earnings surprises (earnings that equal or exceed forecasted earnings). They find that these firms exhibit higher abnormal returns during the year leading up to the latest earnings surprise announcement but that the magnitude declines with the number of consecutive earnings surprises. In addition, they find that the abnormal return surrounding the earnings surprise announcements are significantly positive but also decline in magnitude as the number of consecutive earnings surprises increases.

Gong (2005) presents evidence that as the number of previous positive earnings surprises increases, analysts' forecasts are revised upwards by a larger 
amount. However, the error, as measured by the difference between actual earnings and the analysts' forecast of earnings, becomes larger as a firm extends its series of previous earnings surprise announcements. Gong argues that analysts use the number of previous earnings surprises when making their earnings forecasts.

D’Mello, Tawatnuntachai and Yaman (2003) study abnormal returns around the announcement of seasoned equity offerings (SEOs) conditioned on the number of previous SEOs. They show that abnormal returns become less negative in response to an SEO as the number of previous SEOs increases. The first three SEOs by a firm are associated with significantly negative abnormal returns and subsequent SEOs, with the exception of the fifth, exhibit returns that are not different to zero. This result is robust to controls for firm characteristics such as firm size and market-to-book ratio, firm exchange listing, and the dollar amount of the SEO. In a somewhat related study of U.K. rights offerings, Iqbal (2008) documents significant negative abnormal returns around the first and second rights offering announcement; however, by the third and fourth rights offering announcement, returns are not significantly different to zero.

Elliott and Hanna (1996) investigate the impact of the number of accountingrelated special items, such as write-offs, on stock prices around earnings announcements. Of the firms that declare one large write-off, about half go on to declare a second large write-off within the next three years. The sample of firms continues to decline by half by the time the forth write-off is declared. Thus, once a firm declares a large write-off, there is a reasonably good chance it will subsequently report additional large write-offs. The results show that for firms that have declared multiple large write-offs, abnormal returns exhibit a smaller response to unexpected earnings, relative to firms that have not declared any recent large write-offs. 
Pilotte and Manuel (1996) count the number of stock splits made by a sample of US firms that announce at least two splits between 1970 and 1988. They find that abnormal returns around split announcements are smaller and less significant for firms that frequently split their stock compared to firms that infrequently split. By the sixth split, abnormal returns are statistically indistinguishable from zero. Their evidence suggests that either a stock split eventually becomes anticipated, the signal sent by a stock split announcement becomes weaker, or both. More recently, Huang, et al. (2008) identify all stock splits between 1967 and 2000 and then count only the number of splits in the five years prior to each split announcement. Relative to firms with three or more stock splits, firms with two or fewer splits exhibit a significant difference in return on assets, market-to-book ratio, and the one-year stock price return prior to the split announcement. However, in contrast to the result of Pilotte and Manuel, they find no significant difference in abnormal returns between the two groups around the split announcement.

\section{Sample Selection and Descriptive Statistics}

Dividend information is obtained from the Center for Research in Security Prices (CRSP) database. All taxable regular quarterly dividends (i.e. dividends with a CRSP Distribution Code of 1232) with a declaration date during 1962-2006 are identified. Although this study examines abnormal returns around dividend increase announcements that occur during 1999-2006 only, to calculate of the number of years of prior consecutive dividend increases requires an analysis of firms' entire prior dividend history. ${ }^{4}$

\footnotetext{
${ }^{4}$ For example, one firm in the sample increases its dividend once in 1971 and continues to increase the dividend exactly once every year until the end of the sample is reached in 2006. At the announcement of the dividend increase in the year 1999, this particular firm has a record of 30 consecutive years of
} 
For each firm, year $t$ is defined as the year of the first dividend increase. ${ }^{5}$ If the

following three conditions hold:

(i) Year $t+1$ contains a single dividend increase,

(ii) The amount of each of the dividends between the dividend increase in year $t$ and the dividend preceding the dividend increase in year $t+1$ are all equal, and

(iii) The number of days between the declaration date (DECLDT) of any pair of two consecutive dividends between the dividend increase in year $t$ and the dividend preceding the dividend increase in year $t+1$ is less than 150 days,

then the number of years of consecutive single-year dividend increases corresponding to year $t+1$ is set to ' 1 '. Then, if the three conditions also hold true for year $t+2$, the number of years of consecutive single-year dividend increases is incremented by one to '2', and so on. The identification and counting of dividend increases continues until one of the three conditions fails to hold, or the end of the sample period is reached. Using this counting process, the same firm can have several dividend increase "strings" of varying lengths. ${ }^{6}$ In the case of strings of consecutive earnings increases,

once-a-year dividend increases. Note that firms that increase the dividend multiple times in the same year are not included in the sample.

${ }^{5}$ The first dividend paid by a firm is an initiation and since dividends do not exist prior to an initiation, initiations do not qualify as a dividend increase.

${ }^{6}$ For example, The J.M. Smucker Company commences paying dividends in 1965 and has a total of nine separate strings of consecutive single-year dividend increases. Of these nine strings, two are contained within the sample period 1999 to 2006. One string of increases starts in 1998 and ends in 2000 resulting in a string length of three. Here, the dividend increase in the year 1998 is assigned a ' 1 ', 1999 is assigned a ' 2 ' and 2000 is assigned a ' 3 '. The year 2001 does not contain a dividend increase and thus the string terminates in 2000 with a 'length' of three. A second string commences in 2002 and continues to 2006, the end of the sample. Here, the dividend increase in 2002 is assigned a ' 1 ' and the number assigned to the dividend increase in each subsequent year is increased by one until 2006, which is assigned a ' 5 '. 
a study by Myers et. al. (2007) retains only the longest string for each firm and another study by Barth et. al. (1999) does not make reference to multiple strings implying that their sample might contain more than one string for each firm.

Table I contains the distribution of the dividend increases partitioned by the number of dividend increases and year of announcement for the initial sample. ${ }^{7}$ Reading along each right diagonal, the figure in the cell to the lower right is smaller than the figure for the previous year and previous dividend increase number due to firms that break the string of consecutive dividend increases. For example, 34 firms in 2003 have established a record of four consecutive annual single-year dividend increases. Of these 34 firms, 24 announce a dividend increase in 2004, extending the number of consecutive dividend increases to 5 while 15 announce a further increase in 2005 , extending the string length to 6 .

Almost 40 percent of the sample falls into the category of one dividend increase. As the number of consecutive dividend increases rises, the number of observations in that category falls but at a decreasing rate. For example, in moving from the 1-to-2, 2-to-3, 3-to-4, and 4-to-5 consecutive increases categories, the sample size decreases by about $57 \%, 41 \%, 36 \%$, and $29 \%$, respectively.

About 11 percent of the sample of dividend increases fall under the category of 10 or more consecutive increases. We place the twentieth and higher consecutive dividend increases into a single category, 20+. Less than 3 percent of the total sample of 4,948 dividend increases falls into this category. The fact that a large number of firms have built up such a long record of consecutive regular dividend increases supports Lintner (1958) and Brav et al.'s (2005) contention that managers try to maintain a pattern of smoothly increasing dividends and avoid dividend decreases.

\footnotetext{
${ }^{7}$ For each of exposition dividend increases that represent twenty or more consecutive annual dividend increases are combined in a single dividend-increase-number category of '20 or more'.
} 
The proportion of the number of observations in each category that announce a single dividend increase in the preceding year is presented in Figure I and shows that as the string of consecutive dividend increases gets longer, there is an increasing likelihood that the string will continue. Starting in year one, the proportion of firms that extend the dividend-increase string by one additional year monotonically increases for each of the first eight categories. For firms that have increased the dividend once a year for eight consecutive years or more, the likelihood that the dividend will be increased again in the following year remains remarkably stable at approximately $80 \%$ for each dividend increase category. That a large proportion of firms increase the dividend if the dividend has previously been increased is clear support for Lintner's (1958) finding that managers attempt to maintain a smooth dividend policy. Clearly, the dividend policy of many firms is designed to deliver a pattern of steady dividends to stockholders with regular increases over time.

\section{Descriptive Statistics}

The existing literature shows that abnormal returns around dividend increase announcements are related to a number of firm-specific variables. In this study, we consider four such variables. The CRSP/Compustat Merged Database (CCM) is used to extract accounting data, where appropriate, for the fiscal year-end that precedes the dividend increase announcement date by at least thirty days. The first variable is the market value of equity or Market Cap, which is defined as the product of the stock price and the number of shares outstanding one trading day before the dividend increase announcement date. ${ }^{8}$ The second variable, Market-to-Book Ratio, is included as a proxy for the firm's future growth opportunities and is measured as the market value of equity divided by the total shareholder's equity (The latter variable is CCM

\footnotetext{
${ }^{8}$ If the stock price or number of shares outstanding one trading day before the dividend increase announcement date is unavailable, values on the dividend increase announcement date are used.
} 
Data Item: SEQQ). The third variable, Leverage Ratio, is defined as the ratio of total liabilities to total capital where total liabilities is measured as short-term debt (CCM: DLCQ) plus long-term debt (DLTTQ) and total capital is total liabilities plus the market value of equity, as defined above. The fourth variable, Dividend Change, is the change in the increased dividend relative to the previous quarter's dividend. Table II reports summary statistics for our four firm characteristic variables. The first dividend increase is, on average, the largest increase and represents a 28.8 percent increase compared to the previous dividend. Looking down the columns, we note a near monotonic decline in the mean and median percent change as the length of the dividend-increase string increases. The tendency for the mean change in the dividend to decline for dividend increases that occur later in a dividend-increase string further motivates a more detailed analysis of the abnormal returns around dividend increase announcements partitioned by the number of previous dividend increases. The median market capitalization tends to increase as the number of consecutive dividends increases. This observation indicates that a longer record of consecutive dividend increases is associated with greater firm equity value. No clear patterns are discernible for market-to-book ratios or leverage ratios.

To isolate the abnormal returns due solely to the dividend increase, a sample of dividend increase announcements unaffected by any other corporate announcements is required. This section explains the process of identification of a sample of dividend increase announcements that is unaffected by concurrent announcements. Dividend increase announcement dates are extracted by searching the newswires using the Factiva database. To allow a clean measurement of the stock price reaction to a dividend increase announcement, a dividend increase is discarded from the initial sample if there is another price-sensitive announcement in the period 
within five business days on either side of the Factiva-reported dividend announcement date. ${ }^{9}$ This filtering procedure results in a sample of 1,705 dividend increase announcements during 1999-2006. Thus, approximately one-third of the full sample of dividend increase announcements is free of potentially confounding announcements.

Starting from the non-confounding event sample of 1,705 observations, 106 observations are eliminated due to the unavailability of CCM data. In addition, one observation where the period between the most recent fiscal year-end and the dividend increase announcement date is unusually long is also dropped. Another five observations are eliminated due to negative market-to-book ratios and three outlier observations that have ratios larger than 70 are eliminated. Lastly, six observations are discarded because the dividend increase announcement occurred on a day when the stock market is closed. This identification procedure yields a final sample size of 1,584 dividend increase announcements where the increase is the only increase in a particular year. A result of the reduced sample size is fewer strings of between ten and twenty years of consecutive dividend increase announcements. Therefore, in the remainder of the paper all consecutive single-year dividend increases that last ten or more years are combined into a single category referred to as ' $10+$ '.

Table III provides a breakdown for this sample of 1,584 dividend increase announcements by announcement year and dividend increase number. The number of dividend increases is fairly evenly spread out over the sample time period with the fewest observations, 172, in 2001 and the most observations, 233 , in $2005 .{ }^{10}$ Not

\footnotetext{
${ }^{9}$ Earnings announcements were the most common type of price-sensitive announcements occurring in the vicinity of dividend increase announcements. Other less common announcements include stock split announcements, stock buyback announcements, special dividend declarations, and other announcements such as lawsuits and divestitures.

${ }^{10}$ In contrast to the figures reported in Table I, the figures in each cell in Table III are not always less than the figure in the cell above and to the left. This apparent aberration is merely a consequence of the
} 
surprisingly, the number of observations declines with the number of consecutive dividend increases required except for the grouped category of $10+$.

Descriptive statistics for the firm-specific variables are presented for the final sample in Table IV. Once again, the mean and median market capitalization of dividend-increasing firms increases with the number of consecutive dividend increases. It also appears that the market-to-book ratio rises with the length of the dividend increase string, suggesting that firm value or opportunities are higher for firms that consistently increase their dividends. Mean and median leverage ratios both increase as the number of dividend increases lengthens but peak at the sixth increase and then decreasing slightly with each subsequent increase, giving the relationship a humped shape.

Again, the magnitude of the dividend change declines as the number of consecutive dividend increases lengthens. . For the first dividend increase, the mean (median) increase is $26.0 \%(16.7 \%)$; after ten or more consecutive increases the mean (median) dividend change falls to $8.4 \%(6.7 \%)$.

The values for the market-to-book ratio, leverage ratio and the dividend change for the filtered sample reported in Table IV are similar in magnitude to the corresponding figures reported for the unfiltered sample of dividend increases in Table II. In addition, for each of the first ten dividend-increase-number categories in Table II, a fairly uniform one-third of the observations qualify for the filtered sample in Table IV. However, comparing the market values across the two samples indicates that the mean and median values for the filtered sample are smaller. The median firm has a market value of $\$ 371$ million, which is approximately half the median market

sample construction method. Of the 34 strings of four consecutive increases in 2004 listed in Table I, 27 are eliminated because another price-sensitive announcement occurs in the surrounding days. In comparison only 23 of the 32 strings of five consecutive annual increases in 2005 are discarded due to the occurrence of other price-sensitive announcements around the dividend increase announcement. 
value of $\$ 695$ million for the unfiltered sample. This result indicates that the filter excludes a greater proportion of larger market-value firms compared to smaller market-value firms. Since larger firms tend to disclose more information, in general, than smaller firms, the former firms will have a greater likelihood of making other types of corporate announcements in the vicinity of the dividend increase and therefore not qualify for inclusion in the final sample.

\section{Variable Correlations}

The value of the correlation coefficient between each variable pair is presented in Table V. Market cap and the market-to-book ratio display the highest positive correlation of 0.395 . Market cap and the market-to-book ratio and are negatively correlated with the leverage ratio with correlation coefficients of -0.285 and -0.369 , respectively. This negative correlation is not surprising because market cap appears in the denominator of the leverage ratio, and in the numerator of the market-to-book ratio. Therefore, increases in values of market cap are associated with decreases in the leverage ratio, and vice versa.

\section{Event Study Methodology}

The event study methodology is used to measure abnormal returns around the dividend increase announcement. Day 0 is defined as the event date and is the date the dividend increase announcement appears in the Factiva database. In most cases, newswires report a dividend increase announcement (i.e. press release) on the same day it is declared by the firm's Board of Directors. In a few cases, the newswires report the increase the day after it is declared by the Board, and on rare occasions the dividend is announced up to two weeks after it is declared. ${ }^{11}$ The market reaction to a dividend increase announcement would be expected to occur on the same day it is

\footnotetext{
${ }^{11}$ In the latter case, this delay may be due to a CRSP error, or that the Board meets to declare the increased dividend on a particular day but instead of publicly declaring the dividend increase on the same, or the next, day, it is declared some days later.
} 
reported by the newswires. However, to capture the stock price reaction to announcements reported after the close of trading on Day 0 , abnormal returns are measured over the two-day window $[0,+1] .{ }^{12}$ Abnormal returns are estimated using two methods to ensure that the results are insensitive to the choice of risk-adjustment method. The first method uses market-adjusted returns. Following DeAngelo, DeAngelo and Skinner (1996), the abnormal return is defined the as the stock's raw return minus the return on the value-weighted market index and is calculated as:

$$
A R_{i, t}=R_{i, t}-R_{m, t}
$$

where $A R_{i, t}$ is the abnormal return for stock $i$ for day $t, R_{i, t}$ is the return on stock $i$ for day $t$, and $R_{m, t}$ is the return on the CRSP value-weighted market index for day $t .^{13}$

The second method estimates the risk-adjusted abnormal returns as:

$$
A R_{i, t}=R_{i, t}-\left(\alpha_{i}-\beta_{i} R_{m, t}\right)
$$

where $\alpha_{i}$ and $\beta_{i}$ are the estimates of the intercept and slope respectively for stock $i$ from a market model regression estimated using a maximum estimation length of 255 trading days and a minimum estimation length of 30 trading days computed from data over the interval $[-264,-10]$ relative to the dividend increase announcement date. The remaining variables in equation (2) are as previously defined in equation (1). The 2day cumulative abnormal return for stock $i, \operatorname{CAR}_{i}[0,+1]$, is the sum of the abnormal return for day 0 and day 1 where:

$$
C A R_{i}[0,+1]=A R_{i, 0}+A R_{i, 1}
$$

\footnotetext{
${ }^{12}$ Some studies of dividend changes examine abnormal returns around the three-day event window [-1, $+1]$. These studies typically source announcement dates from the Wall Street Journal Index (WSJI) which contains condensed versions of the original newspaper article reported in the Wall Street Journal (WSJ). A dividend increase announcement made after the WSJ is published, would at the earliest, appear in the following day's edition. Therefore, the announcement date would typically precede the WSJI date by one day. However, there is no reason to expect a stock price reaction before the announcement date when sourced from the newswires and therefore abnormal returns are measured over the two-day event window [-1, 0]. In fact, the results are obtained from using a two-day event window are similar to those for the three-day window.

${ }^{13}$ Grullon et al. (2002) subtract the return on the value-weighted market index from the stock return to measure abnormal returns and obtain similar results when they use the equal-weighted market index instead of the value-weighted market index.
} 
The statistical significance of the abnormal returns is determined following Patell (1976).

\section{Results}

\section{Effect of Length of Dividend-Increase String on Abnormal Returns}

Mean abnormal returns for the two-day dividend increase announcement period partitioned by dividend increase number are reported in Table VI. Across all 1,584 dividend increase announcements the mean market-adjusted abnormal return is $0.31 \%$ and is a slightly lower $0.20 \%$ when measured using risk-adjusted returns. Both figures are however highly significant. An interesting finding emerges when the sample of dividend increases is classified by the number of the dividend increases within a string of consecutive increases. The announcement of the first annual dividend increase is associated with the largest mean market-adjusted abnormal return and risk-adjusted abnormal return of $0.61 \%$ and $0.43 \%$ respectively; both of these figures are highly statistically significant. At the announcement of the second increase both the magnitude and statistical significance of the abnormal returns declines compared to the first increase, but these returns remain significant. However, with the exception of the ninth dividend increase, the third and all subsequent increases display abnormal returns that are not statistically different from zero using either abnormal return measure. These results suggest that the first and second consecutive dividend increases are unexpected, and that by time the third, or later, consecutive dividends are announced, the increases are largely expected. Since both abnormal return measures yield results of a similar magnitude and statistical significance, the remainder of the study presents results using only the marketadjusted returns. The pattern of declining abnormal returns the more often the announcement has been repeated is consistent with the findings of Pilotte and Manuel 
(1968) for repeated stock splits and of Iqbal (2008) for repeated seasoned equity offer announcements and suggests that the number of times a corporate finance event is repeated is an important determinant of the magnitude of the market reaction.

For both abnormal return calculation methods, the evidence presented in Table VI indicates that only the first and second dividend increases are associated with significantly positive abnormal returns. However, Table IV shows that the size of the dividend increase declines as the dividend-increase string gets longer. Therefore, the significant positive abnormal returns found for the first and second consecutive dividend increases may simply be due to the fact that these are, on average, larger dividend changes than those later in a string.

Table VII presents the mean abnormal return by dividend change size and dividend increase number. Rather than forming dividend change quintiles, the results are presented using dividend change categories of five percentage points for comparison with existing literature. For example, Dielman and Oppenheimer (1984) investigate dividend increases that exceed twenty-five percent and document a mean abnormal return of $2.25 \%$ while Yoon and Starks (1995) examine dividend increases of at least ten percent and report a mean abnormal return of $1.15 \%$. In comparison with these two studies, we find a smaller mean abnormal return of $0.73 \%$ for dividend changes of more than twenty-five percent and $0.38 \%$ (not shown in table) for dividend changes of more than ten percent. However, the evidence of variation in dividendincrease announcement period abnormal returns over time documented by $\mathrm{Li}$ and Lie (2006) implies that the results from studies that use different sample periods may not be directly comparable. Also, in contrast to a number of other studies, this study does not trim or winsorize the sample, but we do perform a number of alternative tests to demonstrate the sensitivity of the analysis to the method of sample construction. 
Abnormal returns are approximately $0.20 \%$ around announcements of dividend increases of $10 \%$ or less. Abnormal returns are $-0.01 \%$ for increases of $10 \%-15 \%$ and $0.349 \%$ for increases between $15 \%$ and $20 \%$. The largest abnormal returns are associated with the two largest categories of dividend increases. Abnormal returns are $0.53 \%$ and $0.73 \%$, respectively, for increases of $20-25 \%$ and for increases greater than $25 \%$. That larger dividend increases are associated with larger abnormal returns is consistent with Pettit (1972) and demonstrates that in more recent times, the market continues to interpret dividend increases of all magnitudes as 'good news' albeit at a smaller magnitude.

An examination of the number of observations reported in Table VII reveals a degree of clustering in dividend change amounts within each increase-number class. For all first-time dividend increases, large increases are more frequent than smaller increases. Focusing on changes in the dividend of 15 percent or more as shown in the last column of the table, $54 \%$ of the first increases, $46 \%$ of the second consecutive increases, and $32 \%$ of the third consecutive increases fall into the 15 percent or higher increase categories. A near monotonic pattern continues until only $9 \%$ of the increases in the ten-or-more consecutive dividend increases category are greater than $15 \%$ in magnitude. $^{14}$

\section{Multivariate Results}

As reported in Table VI, abnormal returns are positive and significant for the first two consecutive dividend increases, but are generally not significantly different from zero for subsequent increases. However, as documented in Table IV, the first two increases are, on average, larger, and the firms are smaller, compared to later

\footnotetext{
${ }^{14}$ The corresponding figures for the unfiltered sample of 4,948 dividend increases are similar to those reported in Table VII. For example, of all first-time dividend increases, $54 \%$ increase the dividend by greater than $15 \%$. The proportion monotonically declines until the seventh consecutive increase (19\%), then rises to $23 \%, 24 \%$, and then drops to $16 \%$ for the eighth, ninth and tenth consecutive dividend increases, respectively.
} 
increases. Yoon and Starks (1995) and Lang and Litzenberger (1989) find a difference in abnormal returns around dividend increase announcements depending on the market-to-book ratio which motivates the inclusion of this particular variable in the model. The firm's leverage ratio is included following the evidence of Barth et al. (1999) that firms with at least five years of annual earnings increases have significantly lower debt-equity ratios than other firms. Therefore, we use a regression model to determine if the position of the dividend increase within a string of dividend increases is an important determinant of abnormal returns after controlling for four firm-specific variables. The following equation is estimated:

$$
C A R=\beta_{0}+\beta_{1} C H G+\beta_{2} M V E+\beta_{3} M B R+\beta_{4} L V R+\sum_{i=1, i \neq 5}^{10+} \gamma_{i} D I N U M_{i}
$$

where CAR is the 2-day announcement period abnormal return as defined in equation (3), $\mathrm{CHG}$ is the size of the dividend increase, MVE is the natural logarithm of the market value of the firm's equity, MBR is the firm's market-to-book ratio, and LVR is the firm's book leverage ratio. DINUM $\mathrm{D}_{\mathrm{i}}$ is a dummy variable with a value of one if the dividend increase is the $i$ th consecutive increase in a dividend-increase string, and zero otherwise. The dummy variable that represents five consecutive dividend increases is excluded from equation (4) in order to prevent multicollinearity among the dummy variables that would otherwise occur.

The results of estimating four single-variable specifications of equation (4), and the complete equation, are presented in Table VIII. The first regression equation (Model 1) indicates that the size of the dividend change (CHG) is a positive and significant determinant of abnormal returns. This result implies that larger dividend increases have a greater effect on firm equity value, as found in prior studies. In the second equation (Model 2), the significant negative coefficient on the market value of 
equity (MVE) is also consistent with existing research and suggests that the information contained in a dividend increase announcement is more important for small firms than for large firms. This difference in dividend increase expectations may simply be driven by the more frequent information releases and greater analyst coverage of large market-value firms. The coefficient estimates of the two remaining univariate models indicate that abnormal returns are not significantly related to the market-to-book ratio (MBR) or the leverage ratio (LVR).

Estimated coefficients for the multivariate equation (4) are shown as 'Model 5'. Interestingly, the size of the dividend change is no longer significant in this model. The market value of equity remains a significant determinant of abnormal returns. In addition, the market-to-book ratio and leverage ratio are now significant at the $10 \%$ level, suggesting that firms with higher market-to-book ratios and lower leverage ratios exhibit higher abnormal returns around dividend increase announcements. Since leverage is a substitute for dividends in solving the free cash flow problem, this finding is consistent with the idea that dividend increases play a greater role in reducing agency costs when firms have low leverage.

Turning to the main variables of interest in this study, the number of consecutive dividend increase, we find a significant coefficient for the first and second increase. However, the coefficients for the third and fourth increases are not significant and are much smaller in magnitude. The fifth increase is omitted from the model in order to avoid multicollinearity. However, the coefficients for the sixth through ninth increases are also positive and significant while the coefficient for increases of ten or more is not significant. Figure I indicates that approximately ninety per cent of firms with at least ten years of increases deliver a further increase. This statistic, combined with the knowledge from Lintner (1956) that firms seek to supply 
a smooth pattern of dividend payments, suggests that, with a high probability, once a firm has delivered ten consecutive dividend increases, it will continue to increase dividends in the future. An insignificant abnormal return at the announcement of such increases is consistent with these increases being expected. Of the dividend-increase dummy variables, the ninth increase has the largest coefficient of $1.31 \%$.

Lastly, it should also be noted that the market-to-book ratio becomes significantly positive, albeit at the ten per cent level, when the dividend increase dummy variables are included in the regression. Thus, higher market-to-book firms have a greater response to dividend increases. This observation may suggest that firms with more growth options, which are inherently more difficult to value, benefit more from the signaling effect of dividend increases.

\section{Sensitivity Analysis}

To test whether the results reported in the previous section are robust to the sample construction technique, a number of modifications are made to the original sample and equation (4) is then estimated. The first robustness test is to exclude instances when the stock did not trade on the dividend increase announcement date and this requirement decreases the sample size to 1,471 increase announcements. ${ }^{15}$ The results presented in Table IX under the column heading 'Model 1' are broadly similar to the results for the full sample of 1,584 . The significance levels attached to each of the dummy variables that represent the number of consecutive increases are lower compared to the full sample yet the coefficient values are higher in each case. As explained earlier, firms can have multiple dividend-increase strings. The second robustness test excludes from the sample dividend increase announcements that occur

\footnotetext{
${ }^{15}$ On days a stock does not trade the CRSP-reported price represents the average of the bid and ask, and this average is given a negative sign. In the full sample of 1,584, the price used to form the value MVE is the absolute value of the price.
} 
within 365 days of the termination of a dividend-increase string. The motivation for this second sensitivity check is to require the firm remains out of the sample for one year before the identification of a 'new' dividend increase string can commence. The results for this 'Model 2' are comparable to Model 1 results in terms of statistical significance, with the exception that the second dividend increase announcement is not longer significant.

A number studies (for example, Li and Lie (2006) and Lang and Litzenberger (1989)) exclude utility and financial firms because these firms' dividends tend to be regulated. Therefore, the third robustness check estimates equation (4) excluding utility or financial firms (i.e. firms with a four digit Standard Industrial Classification (SIC) code starting with '4' or '6'). The results, listed under 'Model 3' indicate that the first two dividend increases are significant at the ten percent level. Interestingly, leverage is now strongly significant.

Finally, the fourth sample contains those firms that satisfy each of the three previous filters. This sample of 515 dividend-increasing firms trade on the dividend increase announcement date, do not reenter the sample until at least one year after a break in the string of consecutive increases, and do not belong to the utility or financial industry. The results reported under the heading 'Model 4' that show the first two dividend increase are associated with significant positive abnormal returns are consistent with the findings of the previous three samples.

In summary, the robustness checks provide further support that positive abnormal returns are confined to certain dividend increases only.

\section{Conclusions}


We investigate whether the market learns to anticipate dividend increases by firms with a history of consistently increasing their dividend. Results suggest that the market reaction to dividend increases is positive and significant for the first and second dividend increase and then becomes insignificant for subsequent increases. This is an interesting result in that it suggests that the positive effects of dividend increases are confined to the earliest increases. This is intuitively plausible in that market participants should be able to anticipate dividend increases by firms that have a long history of them. However, it is somewhat surprising that it should happen so quickly.

We also find that a difference in abnormal returns depending on the location of a dividend increase within a string of increases remains after controlling for other determinants of the market reaction such as market capitalization, the market-to-book ratio, leverage, and size of the dividend change, and is robust to several different sample construction methods.

It is clear that the conventional method of grouping together all dividend increases obscures this result. 


\section{References}

Aharony, J. \& Swary, I. 1980, 'Quarterly dividend and earnings announcements and stockholders' returns: An empirical analysis', Journal of Finance, vol. 35, pp. $1-12$.

Amihud, Y. \& Li, K. 2006, 'The declining information content of dividend announcements and the effects of institutional holdings', Journal of Financial and Quantitative Analysis, vol. 41, pp. 637-660.

Asquith, P. \& Mullins, D.W. 1983, 'The impact of initiating dividend payments on shareholders' wealth', Journal of Business, vol. 56, pp. 77-96.

Bajaj, M. \& Vijh, A.M. 1990, 'Dividend clienteles and the information content of dividend changes', Journal of Financial Economics, vol. 26, pp. 193-219.

Barth, M.E., Elliott, J.A. \& Finn, M.W. 1999, 'Market rewards associated with patterns of increasing earnings', Journal of Accounting Research, vol. 37, pp. $387-413$.

Bartov, E., Givoly, D. \& Hayn, C. 2002, 'The rewards to meeting or beating earnings expectations', Journal of Accounting and Economics, vol. 33, pp. 173-204.

Benartzi, S., Michaely, R. \& Thaler, R. 1997, 'Do changes in dividends signal the future or the past?', Journal of Finance, vol. 52, pp. 1007-1034.

Bhattacharya S. 1979, 'Imperfect information, dividend policy, and "the bird in the hand” fallacy', Bell Journal of Economics, vol. 10, pp. 259-270.

Brav, A., Graham, J.R., Harvey, C.R. \& Michaely, R. 2005, 'Payout policy in the 21st century', Journal of Financial Economics, vol. 77, pp. 483-527.

Cheng, L.T.W. \& Leung, T.Y. 2006, 'Revisiting the corroboration effects of earnings and dividend announcements', Accounting and Finance, vol. 46, pp. 221-241.

Christie, W.G. 1994, 'Are dividend omissions truly the cruelest cut of all?', Journal of Financial and Quantitative Analysis, vol. 29, pp. 459-480.

D’Mello, R., Tawatnuntachai, O. \& Yaman D. 2003, 'Does the sequence of seasoned equity offerings matter?', Financial Management, vol. 32, pp. 59-86.

DeAngelo, H., DeAngelo, L. \& Skinner, D. J. 1996, 'Reversal of fortune: Dividend signaling and the disappearance of sustained earnings growth', Journal of Financial Economics, vol. 40, pp 341-371.

Denis, D.J., Denis, D.K. \& Sarin, A. 1994, 'The information content of dividend changes: cash flow signaling, overinvestment, and dividend clienteles', Journal of Financial and Quantitative Analysis, vol. 29, pp. 567-587. 
Dielman, T.E. \& Oppenheimer, H.R. 1984, 'An examination of investor behavior during periods of large dividend changes', Journal of Financial and Quantitative Analysis, vol. 19, pp. 197-216.

Dhillon, U.S. \& Johnson, H. 1994, 'The effect of dividend changes on stock and bond prices', Journal of Finance, vol. 49, pp. 281-289.

Eades, K.M., Hess, P.J. \& Kim, E.H. 1985, 'Market rationality and dividend announcements', Journal of Financial Economics, vol. 14, pp. 581-604.

Easton, S. 1991, 'Earnings and dividends: Is there an interaction effect?', Journal of Business, Finance \& Accounting, vol. 18, pp. 255-266.

Elliott, J.A. \& Hanna, J.D. 1996, 'Repeated accounting write-offs and the information content of earnings', Journal of Accounting Research, vol. 34, pp. 135-155.

Ghosh, C. \& Woolridge, J.R. 1988, 'An analysis of shareholder reaction to dividend cuts and omissions', Journal of Financial Research, vol. 11, pp. 281-294.

Gong, G. 2005, 'Consistent earnings surprises and behavioral biases in analyst forecasts', Working paper. Henry B. Tipple College of Business, Iowa City.

Graham, J.R., Koski, J.L. \& Loewenstein, U. 2006, 'Information flow and liquidity around anticipated and unanticipated dividend announcements', Journal of Business, vol. 79, pp 2301-2336.

Grullon, G., Michaely, R., Benartzi, S. \& Thaler, R.H. 2005, 'Dividend changes do not signal changes in future profitability', Journal of Business, vol. 78, pp. 1659-1682.

Grullon, G., Michaely, R. \& Swaminathan, B. 2002, 'Are dividend changes a sign of firm maturity?', Journal of Business, vol. 75, pp 387-424.

Handjinicolaou, G. \& Kalay, A. 1984, 'Wealth redistributions or changes in firm value: An analysis of returns to bondholders and stockholders around dividend announcements', Journal of Financial Economics, vol. 13, pp. 35-63.

Healy, P.M. \& Palepu, K.G. 1988, 'Earnings information conveyed by dividend initiations and omissions', Journal of Financial Economics, vol. 21, pp. 149175.

Huang, G., Liano, K., Manakyan, H. \& Pan, M. 2008, 'The information content of multiple stock splits', Financial Review, vol. 43, pp. 543-567.

Iqbal, A. 2008, 'The importance of the sequence in UK rights issues', Journal of Business, Finance \& Accounting, vol. 35, pp. 150-176.

Jensen, M. C. 1986, 'Agency costs of free cash flow, corporate finance, and takeovers', American Economic Review, vol. 76, pp. 323-329. 
John, K. \& Williams, J. 1985, 'Dividends, dilution, and taxes: A signaling equilibrium', Journal of Finance, vol. 40, pp. 1053-1070.

Kane, A., Lee, Y.K. \& Marcus, A. 1984, 'Earnings and Dividend Announcements: Is there a corroboration effect?', Journal of Finance, vol. 39, pp. 1091-1099.

Kasznik, R. \& McNichols, M.F. 2002, 'Does meeting earnings expectations matter? Evidence from analyst forecast revisions and share prices', Journal of Accounting Research, vol. 40, pp 727-759.

Lang, L.H.P. \& Litzenberger, R.H. 1989, 'Dividend Announcements: Cash flow signaling vs. Free cash flow hypothesis?', Journal of Financial Economics, vol. 24, pp. 181-191.

Li, W. \& Lie, E. 2006, 'Dividend changes and catering incentives', Journal of Financial Economics, vol. 80, pp. 293-308.

Lintner, J. 1956, 'Distribution of incomes of corporations among dividends, retained earnings, and taxes', American Economic Review, vol. 46, pp. 97-113.

Michaely, R., Thaler, R.H. \& Womack, K.L. 1995, 'Price reactions to dividend initiations and omissions: overreaction or drift?', Journal of Finance, vol. 50, pp. 573-608.

Miller, M.H. \& Modigliani, F. 1961, 'Dividend policy, growth, and the valuation of shares', Journal of Business, vol. 34, pp. 411-433.

Miller, M.H. \& Rock, K. 1985, 'Dividend policy under asymmetric information', Journal of Finance, vol. 40, pp. 1031-1051.

Myers, J.N., Myers, L.A. \& Skinner, D.J. 2007, 'Earnings momentum and earnings management', Journal of Accounting, Auditing \& Finance, vol. 22, pp. 249284.

Nissim, D. \& Ziv, A. 2001, 'Dividend changes and future profitability', Journal of Finance, vol. 56, pp. 2111-2133.

Patell, J.M. 1976, 'Corporate forecasts of earnings per share and stock price behavior: Empirical tests', Journal of Accounting Research, vol. 14, pp. 246-276.

Pettit, R.R. 1972, 'Dividend announcements, security performance, and capital market efficiency', Journal of Finance, vol. 27, pp. 993-1007.

Pilotte, E. \& Manuel, T. 1996, 'The market's response to recurring events: The case of stock splits', Journal of Financial Economics, vol. 41, pp. 111-127.

Watts, R. 1973, 'The information content of dividends', Journal of Business, vol. 46, pp. 191-211. 
Woolridge, J.R. 1983, 'Dividend changes and security prices', Journal of Finance, vol. 38 , pp. 1607-1615.

Yoon, P.S. \& Starks, L.T. 1995, 'Signaling, investment opportunities, and dividend announcements', Review of Financial Studies, vol. 8, pp. 995-1018. 
Figure I

Proportion of firms that increase the dividend by one additional year

The figure shows the ratio of the number of dividend increases for 2000 to 2006 in each dividendincrease-number category to the number of dividend increases for 1999 to 2005 in the preceding dividend-increase-number category for each progression category. The proportions are calculated using the figures reported in Table I but for each progression category $t$-to- $t+1$ the number of increases in 1999 for string length $t+1$ and the number of increases in 2006 for string length $t$ are excluded. This adjustment is required to ensure a reliable measure of the proportion of firms that progress because the number of increases in 1998 for year $t$ and the number of increases in 2007 for year $t+1$ is unknown.




Table I

Distribution of Number of Years of Increases by Announcement Year

This table reports the distribution of dividend increases classified by the number of years of consecutive once-a-year increases and announcement year for a sample of dividend increases occurring between 1999 and 2006. Inclusion in the sample requires that year $t+1$ contains one dividend increase only, the dividends between the increase in year $t$ and before the increase in year $t+1$ and all equal, and any two dividends must be declared within 150 days of each other.

\begin{tabular}{llllllllll}
\hline \multicolumn{7}{c}{ Announcement Year } \\
\hline $\begin{array}{l}\text { Years of } \\
\text { Consecutive }\end{array}$ & 1999 & 2000 & 2001 & 2002 & 2003 & 2004 & 2005 & 2006 & TOTAL \\
Increases & & & & & & & & & \\
1 & 234 & 214 & 202 & 224 & 267 & 307 & 302 & 219 & 1969 \\
2 & 104 & 78 & 72 & 87 & 112 & 125 & 138 & 140 & 856 \\
3 & 71 & 56 & 36 & 45 & 58 & 62 & 91 & 83 & 502 \\
4 & 51 & 40 & 28 & 28 & 34 & 34 & 49 & 58 & 322 \\
5 & 39 & 33 & 23 & 22 & 22 & 24 & 32 & 35 & 230 \\
6 & 24 & 27 & 21 & 17 & 17 & 15 & 15 & 22 & 158 \\
7 & 21 & 17 & 23 & 16 & 13 & 17 & 10 & 10 & 127 \\
8 & 19 & 14 & 16 & 21 & 12 & 9 & 15 & 8 & 114 \\
9 & 16 & 17 & 11 & 13 & 19 & 11 & 7 & 11 & 105 \\
10 & 3 & 15 & 12 & 11 & 12 & 12 & 10 & 5 & 80 \\
11 & 4 & 2 & 10 & 10 & 10 & 9 & 9 & 7 & 61 \\
12 & 7 & 3 & 2 & 8 & 8 & 7 & 7 & 8 & 50 \\
13 & 11 & 3 & 2 & 1 & 8 & 7 & 6 & 5 & 43 \\
14 & 12 & 10 & 3 & 1 & 1 & 6 & 7 & 5 & 45 \\
15 & 4 & 10 & 7 & 3 & 1 & 1 & 6 & 7 & 39 \\
16 & 5 & 3 & 7 & 7 & 1 & 1 & 1 & 5 & 30 \\
17 & 7 & 4 & 2 & 6 & 6 & 1 & 1 & 1 & 28 \\
18 & 2 & 6 & 3 & 2 & 5 & 3 & 1 & 1 & 23 \\
19 & 1 & 2 & 6 & 3 & 2 & 5 & 3 & 0 & 22 \\
$20+$ & 15 & 15 & 14 & 18 & 20 & 19 & 21 & 22 & 144 \\
\hline TOTAL & 650 & 569 & 500 & 543 & 628 & 675 & 731 & 652 & 4948 \\
\hline
\end{tabular}




\section{Table II}

\section{Summary Statistics for Initial Sample}

The table reports the mean and median values for four firm-specific variables for a sample of 4,717 dividend increases with a declaration date between January 1, 1999 and December 31, 2006. Strings of twenty or more consecutive dividend increases are combined in a single category labeled ' $20+$ '. The total sample size of 4,948 in Table I is greater than the total of 4,717 here because of missing financial data in the CRSP/Compustat Merged Database. Six observations with abnormally large percentage changes as a result of CRSP recording errors are also excluded.

\begin{tabular}{|c|c|c|c|c|c|c|c|c|c|}
\hline \multirow{3}{*}{$\begin{array}{l}\text { Years of } \\
\text { Consecutive }\end{array}$} & \multirow[b]{2}{*}{$n$} & \multicolumn{2}{|c|}{ Market cap } & \multicolumn{2}{|c|}{ Market-to-book } & \multicolumn{2}{|c|}{ Leverage ratio } & \multicolumn{2}{|c|}{ Dividend change } \\
\hline & & Mean & Median & Mean & Median & Mean & Median & Mean & Median \\
\hline & & & & & & & & & \\
\hline Increases & & & & & & & & & \\
\hline 1 & 1820 & 4871 & 467 & 2.51 & 1.86 & 0.30 & 0.26 & 0.288 & 0.167 \\
\hline 2 & 821 & 5665 & 612 & 2.66 & 1.93 & 0.31 & 0.27 & 0.204 & 0.143 \\
\hline 3 & 487 & 5529 & 653 & 2.50 & 2.00 & 0.31 & 0.28 & 0.182 & 0.125 \\
\hline 4 & 318 & 7379 & 671 & 2.57 & 2.02 & 0.32 & 0.28 & 0.152 & 0.116 \\
\hline 5 & 228 & 6322 & 550 & 2.53 & 1.98 & 0.33 & 0.31 & 0.126 & 0.100 \\
\hline 6 & 156 & 5909 & 531 & 2.41 & 1.94 & 0.36 & 0.33 & 0.125 & 0.100 \\
\hline 7 & 126 & 6926 & 644 & 2.53 & 1.92 & 0.34 & 0.32 & 0.115 & 0.100 \\
\hline 8 & 112 & 5947 & 1004 & 2.94 & 2.16 & 0.31 & 0.25 & 0.116 & 0.098 \\
\hline 9 & 102 & 6606 & 1243 & 3.28 & 2.15 & 0.32 & 0.29 & 0.143 & 0.091 \\
\hline 10 & 76 & 7974 & 1566 & 3.12 & 2.36 & 0.30 & 0.27 & 0.107 & 0.083 \\
\hline 11 & 58 & 7280 & 1464 & 2.98 & 2.31 & 0.27 & 0.22 & 0.112 & 0.098 \\
\hline 12 & 48 & 11310 & 1943 & 3.74 & 2.51 & 0.26 & 0.19 & 0.131 & 0.100 \\
\hline 13 & 40 & 11747 & 1739 & 3.42 & 2.26 & 0.24 & 0.15 & 0.092 & 0.080 \\
\hline 14 & 43 & 10110 & 2120 & 4.19 & 2.20 & 0.25 & 0.21 & 0.117 & 0.067 \\
\hline 15 & 37 & 13734 & 2687 & 3.42 & 2.11 & 0.25 & 0.20 & 0.080 & 0.069 \\
\hline 16 & 29 & 18328 & 2979 & 3.27 & 2.32 & 0.23 & 0.18 & 0.098 & 0.067 \\
\hline 17 & 27 & 16830 & 1631 & 2.48 & 1.96 & 0.24 & 0.18 & 0.061 & 0.048 \\
\hline 18 & 23 & 11414 & 1955 & 2.53 & 2.17 & 0.27 & 0.28 & 0.072 & 0.050 \\
\hline 19 & 22 & 7138 & 2245 & 2.47 & 2.25 & 0.29 & 0.26 & 0.065 & 0.047 \\
\hline $20+$ & 144 & 16183 & 3660 & 3.51 & 2.44 & 0.21 & 0.17 & 0.083 & 0.056 \\
\hline Total & 4717 & 6329 & 695 & 2.66 & 1.96 & 0.30 & 0.27 & 0.206 & 0.120 \\
\hline
\end{tabular}




\section{Table III}

\section{Sample Distribution by Year and Dividend Increase Number}

This table contains the number of dividend increases announcements classified by the announcement year and the dividend increase number for a sample of 1,584 quarterly dividend increases announced by US firms between January 1, 1999 and December 31, 2006. Strings of ten or more consecutive annual dividend increases are combined in a single category labeled ' $10+$ '.

\begin{tabular}{|c|c|c|c|c|c|c|c|c|c|c|}
\hline $\begin{array}{l}\text { Years of } \\
\text { Consecutive } \\
\text { Increases }\end{array}$ & 1999 & 2000 & 2001 & 2002 & 2003 & 2004 & 2005 & 2006 & Total & $\begin{array}{l}\% \text { of } \\
\text { Total }\end{array}$ \\
\hline 1 & 65 & 79 & 59 & 78 & 85 & 83 & 93 & 65 & 607 & $38.3 \%$ \\
\hline 2 & 31 & 30 & 34 & 31 & 36 & 34 & 43 & 40 & 279 & $17.6 \%$ \\
\hline 3 & 29 & 19 & 12 & 21 & 18 & 20 & 22 & 18 & 159 & $10.0 \%$ \\
\hline 4 & 23 & 15 & 11 & 8 & 13 & 7 & 19 & 16 & 112 & $7.1 \%$ \\
\hline 5 & 13 & 16 & 4 & 7 & 6 & 12 & 9 & 6 & 73 & $4.6 \%$ \\
\hline 6 & 9 & 9 & 9 & 6 & 7 & 5 & 5 & 8 & 58 & $3.7 \%$ \\
\hline 7 & 5 & 7 & 12 & 7 & 3 & 7 & 6 & 4 & 51 & $3.2 \%$ \\
\hline 8 & 7 & 4 & 10 & 8 & 8 & 1 & 6 & 3 & 47 & $3.0 \%$ \\
\hline 9 & 3 & 6 & 3 & 3 & 7 & 4 & 1 & 5 & 32 & $2.0 \%$ \\
\hline $10+$ & 22 & 19 & 18 & 19 & 23 & 18 & 29 & 18 & 166 & $10.5 \%$ \\
\hline Total & 207 & 204 & 172 & 188 & 206 & 191 & 233 & 183 & 1,584 & $100.0 \%$ \\
\hline$\%$ of Total & $13.1 \%$ & $12.9 \%$ & $10.9 \%$ & $11.9 \%$ & $13.0 \%$ & $12.1 \%$ & $14.7 \%$ & $11.6 \%$ & $100.0 \%$ & \\
\hline
\end{tabular}




\section{Table IV \\ Descriptive Statistics for Dividend Increases without Concurrent \\ Announcements}

The table contains firm-specific descriptive statistics for four variables used in the analysis partitioned by dividend increase number for a sample 1,584 quarterly dividend increases announced by US firms between January 1, 1999 and December 31, 2006. Strings of ten or more years of consecutive singleyear dividend increases are combined in a single category labeled '10+'. Market cap is the market value of equity (in \$ millions) and is the product of the stock price and the number of shares outstanding one trading day before the dividend increase announcement date. The market-to-book ratio is the market value of equity divided by the total shareholder's equity. The leverage ratio is the ratio of total liabilities to total capital where total liabilities is measured as short-term debt plus longterm debt and total capital is total liabilities plus the market value of equity. Dividend change is the change in the dividend relative to the previous quarterly dividend. Accounting variable values are for the fiscal year end date that precedes the dividend increase announcement date by at least thirty days.

\begin{tabular}{lccccccccc}
\hline & \multicolumn{4}{c}{ Market cap } & \multicolumn{2}{c}{ Market-to-book } & \multicolumn{2}{c}{ Leverage ratio } & \multicolumn{2}{c}{ Dividend change } \\
\hline $\begin{array}{l}\text { Years of } \\
\text { Consecutive } \\
\text { Increases }\end{array}$ & $n$ & Mean & Median & Mean & Median & Mean & Median & Mean & Median \\
1 & 607 & 1682 & 223 & 2.24 & 1.68 & 0.30 & 0.27 & 0.260 & 0.167 \\
2 & 279 & 2841 & 307 & 2.58 & 1.91 & 0.32 & 0.29 & 0.194 & 0.143 \\
3 & 159 & 2006 & 336 & 2.19 & 1.81 & 0.33 & 0.34 & 0.157 & 0.111 \\
4 & 112 & 2191 & 433 & 2.38 & 2.02 & 0.32 & 0.31 & 0.167 & 0.121 \\
5 & 73 & 2236 & 357 & 2.49 & 1.86 & 0.36 & 0.37 & 0.099 & 0.080 \\
6 & 58 & 2984 & 468 & 2.28 & 1.92 & 0.41 & 0.39 & 0.108 & 0.093 \\
7 & 51 & 8591 & 841 & 2.45 & 1.91 & 0.32 & 0.32 & 0.100 & 0.083 \\
8 & 47 & 6434 & 860 & 2.65 & 2.14 & 0.30 & 0.25 & 0.113 & 0.096 \\
9 & 32 & 2548 & 455 & 2.67 & 2.09 & 0.30 & 0.26 & 0.122 & 0.086 \\
$10+$ & 166 & 4480 & 1541 & 2.92 & 1.93 & 0.25 & 0.21 & 0.084 & 0.067 \\
\hline Total & 1584 & 2702 & 371 & 2.42 & 1.85 & 0.31 & 0.28 & 0.188 & 0.111 \\
\hline
\end{tabular}




\section{Table V}

\section{Correlation Matrix}

The table reports the correlation coefficient between each pair of variables for a sample 1,584 quarterly dividend increases announced by US firms between January 1, 1999 and December 31, 2006. CAR is the two-day cumulative market-adjusted return. Market cap is the market value of equity (in \$ millions) and is the product of the stock price and the number of shares outstanding one trading day before the dividend increase announcement date. The market-to-book ratio is the market value of equity divided by the total shareholder's equity. The leverage ratio is the ratio of total liabilities to total capital where total liabilities is measured as short-term debt plus long-term debt and total capital is total liabilities plus the market value of equity. Dividend change is the change in the dividend relative to the previous quarterly dividend. Accounting variable values are for the fiscal year end date that precedes the dividend increase announcement date by at least thirty days.

\begin{tabular}{lrrrrr}
\hline & CAR & Market cap & $\begin{array}{c}\text { Market-to-book } \\
\text { ratio }\end{array}$ & $\begin{array}{c}\text { Leverage } \\
\text { ratio }\end{array}$ & Dividend change \\
\hline CAR & 1 & & & & \\
Market cap & -0.075 & 1 & 1 & & \\
Market-to-book ratio & 0.025 & 0.395 & -0.369 & 1 & \\
Leverage ratio & -0.039 & -0.285 & 0.066 & -0.058 & 1 \\
Dividend change & 0.053 & -0.026 & & & \\
\hline
\end{tabular}


Table VI

\section{Mean Abnormal Return}

This table reports the two-day abnormal return (expressed in percent) around the dividend increase announcement date for a sample of 1,584 dividend increase announcements with a declaration date between January 1, 1999 and December 31, 2006 classified by the number of consecutive years of single-year dividend increases. The dividend increase announcement is the only price-sensitive announcement that occurs in the five trading days on either side of the announcement date. Strings of ten or more consecutive annual dividend increases are combined in a single category labeled '10+'.

\begin{tabular}{|c|c|c|c|c|c|}
\hline \multirow[b]{2}{*}{ Years of } & \multirow[b]{3}{*}{$\mathrm{n}$} & \multicolumn{2}{|c|}{ Market-adjusted returns } & \multicolumn{2}{|c|}{ Risk-adjusted returns } \\
\hline & & $\mathrm{CAR}[0,+1]$ & Z-statistic & $\operatorname{CAR}[0,+1]$ & Z-statistic \\
\hline Consecutive & & & & & \\
\hline \multicolumn{6}{|l|}{ Increases } \\
\hline 1 & 607 & 0.608 & $4.47^{* * *}$ & 0.426 & $3.59^{* * *}$ \\
\hline 2 & 279 & 0.348 & $1.84^{* *}$ & 0.277 & $1.68^{* *}$ \\
\hline 3 & 159 & -0.175 & -0.01 & -0.155 & -0.04 \\
\hline 4 & 112 & -0.077 & -0.06 & -0.064 & -0.11 \\
\hline 5 & 73 & -0.472 & -0.98 & -0.387 & -0.54 \\
\hline 6 & 58 & 0.521 & 1.22 & 0.146 & 0.57 \\
\hline 7 & 51 & 0.439 & 0.95 & 0.237 & 0.65 \\
\hline 8 & 47 & 0.520 & 0.98 & 0.472 & 1.03 \\
\hline 9 & 32 & 0.847 & $1.80^{* *}$ & 0.452 & $1.62^{*}$ \\
\hline $10+$ & 166 & -0.078 & -0.35 & -0.065 & -0.22 \\
\hline TOTAL & 1584 & 0.307 & $4.02^{* * *}$ & 0.203 & $3.33^{* * *}$ \\
\hline
\end{tabular}


Table VII

Mean Abnormal Return by Magnitude of Dividend Increase

This table reports the two-day market-adjusted return (CAR) (expressed in percent) around the dividend increase announcement date for a sample of dividend increase announcements with a declaration date between January 1, 1999 and December 31, 2006 classified by the number of consecutive once-a-year dividend increases. The dividend increase announcement is the only price-sensitive announcement that occurs in the five trading days either side of the announcement date. Strings of ten or more consecutive annual dividend increases are combined in a single category labeled '10+'. CHG is the change in the dividend relative to the previous quarterly dividend. Due to small numbers of observations in some cells significance levels, when appropriate, are reported only for the first four, and the tenth, consecutive once-a-year dividend increase, for each dividend change size.

\begin{tabular}{|c|c|c|c|c|c|c|c|c|c|c|c|c|c|}
\hline \multirow{3}{*}{$\begin{array}{l}\text { Years of } \\
\text { Consecutive } \\
\text { Increases }\end{array}$} & \multicolumn{12}{|c|}{ Size of the Dividend Change } & \multirow{3}{*}{$\begin{array}{l}\% \text { of obs } \\
\text { in } \geq 15 \% \\
\text { category }\end{array}$} \\
\hline & \multicolumn{2}{|c|}{$\mathrm{CHG}<5 \%$} & \multicolumn{2}{|c|}{$5 \% \leq \mathrm{CHG}<10 \%$} & \multirow{2}{*}{$\begin{array}{c}10 \% \leq \mathrm{CHG} \\
n\end{array}$} & \multirow{2}{*}{$\begin{array}{l}<15 \% \\
\text { CAR }\end{array}$} & \multicolumn{2}{|c|}{$15 \% \leq \mathrm{CHG}<20 \%$} & \multicolumn{2}{|c|}{$20 \% \leq \mathrm{CHG}<25 \%$} & \multicolumn{2}{|c|}{$\mathrm{CHG} \geq 25 \%$} & \\
\hline & $n$ & CAR & $n$ & CAR & & & $n$ & CAR & $n$ & CAR & $n$ & CAR & \\
\hline 1 & 58 & -0.062 & 107 & $0.545^{*}$ & 112 & $0.558^{*}$ & 53 & -0.117 & 80 & $0.945^{* * *}$ & 197 & $0.927^{* * *}$ & $54.4 \%$ \\
\hline 2 & 31 & 0.235 & 63 & -0.034 & 57 & 0.323 & 31 & 0.641 & 29 & 0.614 & 68 & $0.526^{*}$ & $45.9 \%$ \\
\hline 3 & 24 & -0.075 & 44 & -0.076 & 40 & -0.720 & 16 & 0.196 & 14 & 0.470 & 21 & -0.170 & $32.1 \%$ \\
\hline 4 & 19 & 0.464 & 28 & -0.661 & 26 & -0.124 & 7 & 1.708 & 13 & -1.469 & 19 & 0.600 & $34.8 \%$ \\
\hline 5 & 17 & -0.516 & 25 & -0.493 & 15 & -0.784 & 9 & 0.407 & 5 & -0.672 & 2 & -0.925 & $21.9 \%$ \\
\hline 6 & 10 & 1.252 & 20 & 0.728 & 17 & -0.620 & 6 & 0.470 & 2 & 2.823 & 3 & 1.750 & $19.0 \%$ \\
\hline 7 & 13 & 0.629 & 19 & 0.914 & 12 & -0.557 & 2 & 0.781 & 3 & 0.048 & 2 & 0.919 & $13.7 \%$ \\
\hline 8 & 8 & 0.366 & 19 & 1.240 & 12 & -0.532 & 3 & 1.973 & 1 & 2.877 & 4 & -1.113 & $17.0 \%$ \\
\hline 9 & 6 & 4.065 & 13 & -0.231 & 6 & -0.512 & 2 & 2.252 & 1 & -2.534 & 4 & 1.702 & $21.9 \%$ \\
\hline $10+$ & 61 & -0.072 & 60 & 0.105 & 30 & -0.495 & 5 & -0.091 & 5 & -0.390 & 5 & 0.465 & $9.0 \%$ \\
\hline Total & 247 & $0.184^{*}$ & 398 & 0.203 & 327 & -0.014 & 134 & 0.349 & 153 & $0.534^{* *}$ & 325 & $0.727^{* * *}$ & $38.6 \%$ \\
\hline
\end{tabular}

$*, * *$, and $* * *$ denote statistical significance at the $10 \%, 5 \%$ and $1 \%$ levels, respectively. 


\section{Table VIII \\ Regression Results}

The table reports the results of estimating five different specifications of the equation $\mathrm{CAR}=\beta_{0}+\beta_{1} \mathrm{CHG}+\beta_{2} \mathrm{MVE}+\beta_{3} \mathrm{MBR}+\beta_{4} \mathrm{LVR}+\sum \gamma_{\mathrm{i}} \mathrm{DINUM} \mathrm{M}_{\mathrm{i}}$

for a sample of 1,584 dividend increases with a declaration date between January 1, 1999 and December 31,2006 . CAR is the two-day cumulative market-adjusted abnormal return, CAR $[0,+1]$. CHG is the dividend change calculated as the change in the dividend compared to the previous quarterly dividend. lnMVE is the natural logarithm of the market value of equity (in $\$$ millions) where the market value of equity (MVE) is calculated as the product of the stock price and the number of shares outstanding one trading day before the dividend increase announcement date. The leverage ratio (LVR) is calculated as total current liabilities plus total non-current liabilities divided by the sum of total current liabilities, total non-current liabilities and MVE The market-to-book ratio (MBR) is calculated as MVE divided by total shareholders' equity. DINUM $\mathrm{M}_{\mathrm{i}}$ is a dummy variable that equals one if the dividend increase represents the $i$ th consecutive annual increase where $i$ ranges from 1 to $10+$ (i.e. ten or more) and DINUM ${ }_{5}$ is the omitted dummy variable. The row headed 'R-squared' reports the adjusted R-squared. Two-tailed t-statistics are in parentheses.

\begin{tabular}{|c|c|c|c|c|c|}
\hline Variable & Model 1 & Model 2 & Model 3 & Model 4 & Model 5 \\
\hline Constant & $\begin{array}{l}0.201 \\
(2.30)^{* *}\end{array}$ & $\begin{array}{l}1.732 \\
(3.59)^{* * *}\end{array}$ & $\begin{array}{l}0.228 \\
(2.16)^{* *}\end{array}$ & $\begin{array}{l}0.455 \\
(3.81)^{* * *}\end{array}$ & $\begin{array}{l}1.411 \\
(2.18)^{* *}\end{array}$ \\
\hline $\mathrm{CHG}$ & $\begin{array}{l}0.568 \\
(2.11)^{* * *}\end{array}$ & & & & $\begin{array}{l}0.326 \\
(1.18)\end{array}$ \\
\hline $\operatorname{lnMVE}$ & & $\begin{array}{l}-0.110 \\
(-2.98)^{* * *}\end{array}$ & & & $\begin{array}{l}-0.144 \\
(-3.44)^{* * *}\end{array}$ \\
\hline MBR & & & $\begin{array}{l}0.033 \\
(1.01)\end{array}$ & & $\begin{array}{l}0.061 \\
(1.66)^{*}\end{array}$ \\
\hline LVR & & & & $\begin{array}{l}-0.473 \\
(-1.54)\end{array}$ & $\begin{array}{l}-0.567 \\
(-1.69)^{*}\end{array}$ \\
\hline DINUM $_{1}$ & & & & & $\begin{array}{l}0.952 \\
(2.70)^{* * *}\end{array}$ \\
\hline $\mathrm{DINUM}_{2}$ & & & & & $\begin{array}{l}0.749 \\
(2.02)^{* *}\end{array}$ \\
\hline DINUM $_{3}$ & & & & & $\begin{array}{l}0.265 \\
(0.67)\end{array}$ \\
\hline DINUM $_{4}$ & & & & & $\begin{array}{l}0.358 \\
(0.85)\end{array}$ \\
\hline DINUM $_{6}$ & & & & & $\begin{array}{l}1.066 \\
(2.16)^{* *}\end{array}$ \\
\hline $\mathrm{DINUM}_{7}$ & & & & & $\begin{array}{l}0.987 \\
(1.92)^{*}\end{array}$ \\
\hline DINUM $_{8}$ & & & & & $\begin{array}{l}1.048 \\
(1.99)^{* *}\end{array}$ \\
\hline DINUM $_{9}$ & & & & & $\begin{array}{l}1.310 \\
(2.20)^{* *}\end{array}$ \\
\hline DINUM $_{10+}$ & & & & & $\begin{array}{l}0.488 \\
(1.23)\end{array}$ \\
\hline R-squared & 0.002 & 0.005 & 0.000 & 0.001 & 0.017 \\
\hline F-statistic & $4.47^{* *}$ & $8.91^{* * *}$ & 1.01 & 2.37 & $3.12^{* * *}$ \\
\hline
\end{tabular}




\section{Table IX \\ Robustness Checks}

The table reports the results of estimating the equation

$\mathrm{CAR}=\beta_{0}+\beta_{1} \mathrm{CHG}+\beta_{2} \mathrm{MVE}+\beta_{3} \mathrm{MBR}+\beta_{4} \mathrm{LVR}+\sum \gamma_{\mathrm{i}} \mathrm{DINUM}$

for four different samples of dividend increases with a declaration date between January 1, 1999 and

December 31, 2006. CAR is the two-day cumulative market-adjusted return, CAR $[0,+1]$, CHG is the size of the dividend change, $\ln \mathrm{MVE}$ is the natural logarithm of the market value of equity, MBR is the market-to-book ratio, LVR is the leverage ratio, and DINUM $\mathrm{i}_{\mathrm{i}}$ a dummy variable that equals one if the dividend increase represents the $i$ th consecutive annual increase where $i$ ranges from 1 to $10+$ (i.e. ten or more) and DINUM ${ }_{5}$ is the omitted dummy variable. The row headed ' $R$-squared' reports the adjusted R-squared. Two-tailed t-statistics are in parentheses. Model 1 reports the results for the sample of dividend increase announcements where the announcing firm's stock trades on the dividend increase announcement date. Model 2 reports the results for a sample where the dividend increase is declared at least 365 days after the last dividend increase. Model 3 excludes utility and financial firms from the sample. Model 4 is the sample of firms that represent the intersection of the samples of Models 1,2 and 3 . The row headed ' $\mathrm{R}$-squared' reports the adjusted R-squared. Two-tailed t-statistics are in parentheses.

\begin{tabular}{lllll}
\hline Variable & Model 1 & Model 2 & Model 3 & Model 4 \\
\hline Constant & 1.479 & 1.671 & 2.427 & 2.251 \\
& $(2.18)^{* *}$ & $(2.44)^{* *}$ & $(2.14)^{* *}$ & $(1.81)^{*}$ \\
CHG & 0.325 & 0.359 & 0.338 & 0.349 \\
& $(1.18)$ & $(1.18)$ & $(0.90)$ & $(0.90)$ \\
lnMVE & -0.145 & -0.156 & -0.210 & -0.210 \\
& $(-3.33)^{* * *}$ & $(-3.54)^{* * *}$ & $(-2.84)^{* * *}$ & $(-2.67)^{* * *}$ \\
MBR & 0.064 & 0.072 & 0.030 & 0.039 \\
& $(1.77)^{*}$ & $(1.87)^{*}$ & $(0.65)$ & $(0.82)$ \\
LVR & -0.396 & -0.491 & -2.179 & -2.034 \\
& $(-1.15)$ & $(-1.39)$ & $(-2.74)^{* * *}$ & $(-2.38)^{* *}$ \\
DINUM $_{1}$ & 0.865 & 0.841 & 1.144 & 1.320 \\
& $(2.38)^{* *}$ & $(2.24)^{* *}$ & $(1.81)^{*}$ & $(1.89)^{*}$ \\
DINUM $_{2}$ & 0.637 & 0.592 & 1.128 & 1.242 \\
& $(1.67)^{*}$ & $(1.50)$ & $(1.70)^{*}$ & $(1.70)^{*}$ \\
DINUM $_{3}$ & 0.160 & 0.148 & 0.618 & 0.766 \\
& $(0.39)$ & $(0.35)$ & $(0.85)$ & $(0.97)$ \\
DINUM $_{4}$ & 0.298 & 0.236 & 1.023 & 1.327 \\
& $(0.69)$ & $(0.52)$ & $(1.38)$ & $(1.63)$ \\
DINUM $_{6}$ & 0.928 & 0.923 & 1.262 & 1.264 \\
& $(1.81)^{*}$ & $(1.71)$ & $(1.37)$ & $(1.23)$ \\
DINUM $_{7}$ & 0.752 & 0.807 & 0.499 & 0.565 \\
& $(1.43)$ & $(1.48)$ & $(0.54)$ & $(0.57)$ \\
DINUM $_{8}$ & 0.853 & 0.801 & 1.841 & 1.969 \\
& $(1.61)$ & $(1.46)$ & $(1.87)^{*}$ & $(1.91)^{*}$ \\
DINUM $_{9}$ & 1.312 & 1.374 & 0.909 & 1.527 \\
& $(2.10)^{* *}$ & $(2.20)^{* *}$ & $(0.85)$ & $(1.32)$ \\
DINUM $_{10+}$ & 0.409 & 0.342 & 1.148 & 1.273 \\
& $(1.01)$ & $(0.81)$ & $(1.64)$ & $(1.66)^{*}$ \\
& & & & \\
$n$ & 1,471 & 1,442 & 563 & 515 \\
R-squared $^{*}$ & 0.016 & 0.017 & 0.022 & 0.018 \\
F-statistic $^{*}$ & $2.81^{* * *}$ & $2.93^{* * *}$ & $1.97^{* *}$ & $1.74^{* *}$ \\
\hline
\end{tabular}

$*, * *$, and ${ }^{* * *}$ denote statistical significance at the $10 \%, 5 \%$ and $1 \%$ levels, respectively. 